\title{
Uranium in the History of Medicine
}

\author{
Fathi Habashi* \\ Department of Mining, Laval University, Canada
}

*Corresponding author: : Fathi Habashi, Department of Mining, Metallurgical and Materials

Engineering, Laval University, Quebec City, Canada.

Received Date: May 20 , 2019

Published Date: June 12, 2019

\begin{abstract}
Joachimsthal in Saxony was an important silver mining district since the Middle Ages when around the 1770s production started to decrease and the mining town was about to become a ghost town. It was at that time that Martin Heinrich Klaproth (1743-1817) a pharmacist in Berlin who became later professor of chemistry at the Royal Mining Academy, discovered that the black mineral in the ore can be used to give glass a brilliant yellow color with green fluorescence when added to the molten batch. He was also convinced that this mineral must have contained a new metal. This discovery coincided with the discovery in 1781 of a new planet in the solar system by his compatriot William Herschel who had immigrated to England in 1757 and called the planet Uranus. Hence Klaproth named the new metal "uranium" to honor his compatriot. In 1789 he was able to isolate a black heavy solid from the ore which he thought it to be the new metal. Since that time uranium started to play a dominant role in the history of medicine.
\end{abstract}

\section{Introduction}

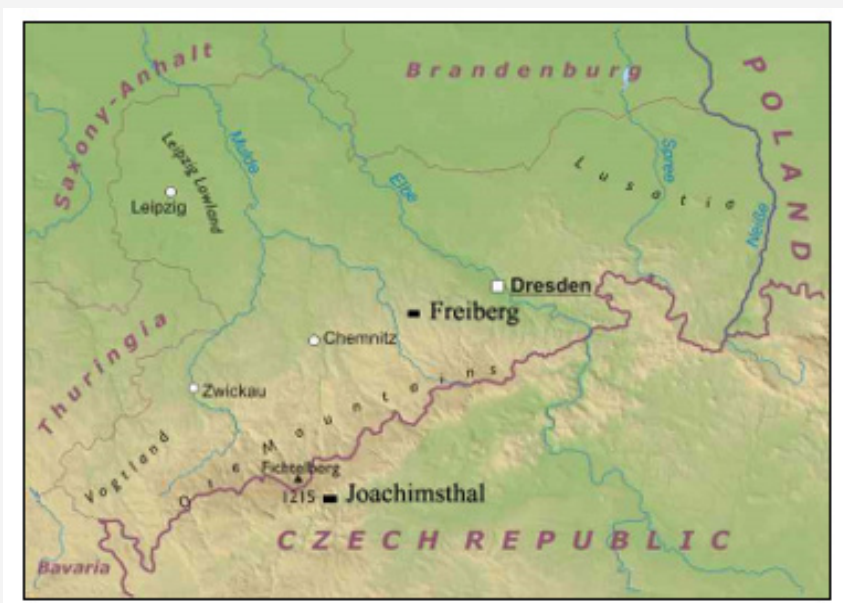

Figure 1: Ore Mountains [Erzgebirge] showing Joachimsthal and Freiberg.

The history of uranium is closely connected with the silver mining town Joachimsthal ${ }^{1}$ in the Erzgebirge on the border between Saxony and Bohemia (Figure 1). The town was founded in 1516 when few years earlier silver was discovered. Further settlings in the neighborhood, Freiberg (1168) and Schneeberg (1446) are also known by their silver discoveries. It was there in Joachimsthal that uranium was discovered but uranium industry went through many stages of prosperity and depression with different industrial products other than uranium till finally uranium became the most sought-after metal during World War II that started in Europe in 1939 [1].

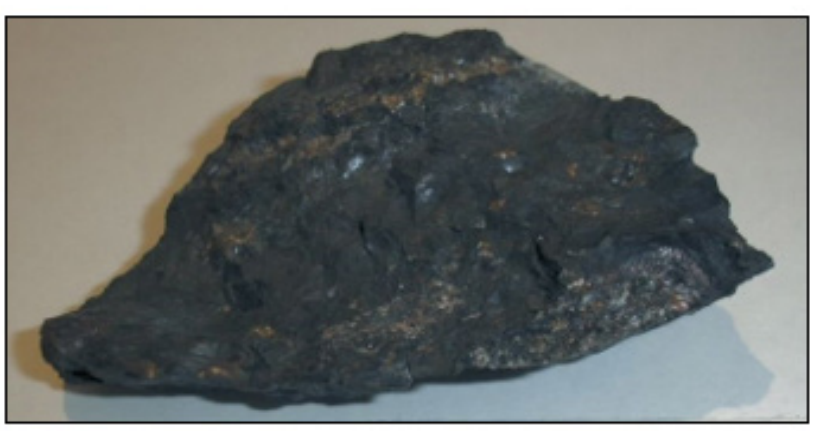

Figure 2: The black mineral in silver ores that contains no silver.

${ }^{1}$ Joachimsthal (Joachim's Valley) is Jachymov in Czech and the Erzgebirge (Ore Mountains) is Krušné Hory. The German names are used here in the text when the Kingdom of the Lands of Czech consisting of Bohemia, Moravia, and Silesia were part of the Austrian Empire while the Czech names after World War I when the Republic of Czechoslovakia was founded. 
Within few years of mining in the district, it became known that the miners in the town suffered from a mysterious sickness. It was also too often that the miners came across a heavy black mineral which was for them a bad luck because it did not contain silver (Figure 2). For this reason they called it "Pechblende" which is German for "the bad luck mineral". Because it was black, it became known in English as "pitchblend". Soon, the miners' sickness was attributed to this black mineral.

The town recognized remarkable prosperity, the population increased gradually, becoming the second largest town in Bohemia after Prague. However, during the religious war of 1546-1547 and the lack of pumps needed to remove water from the deep mines made it difficult to compete with silver from the new Spanish American colonies, which was arriving in increasing quantities on the European market. As a result, the town knew its depression and the population decreased drastically. With decreased silver production, Joachimsthal was about to become a ghost town when Martin Klaproth (1743-1817) (Figure 3) a pharmacist in Berlin who became later professor of chemistry at the Royal Mining Academy in Berlin, discovered that the black mineral from Joachimsthal can be used to give glass a brilliant yellow color with green fluorescence when added to the molten batch.

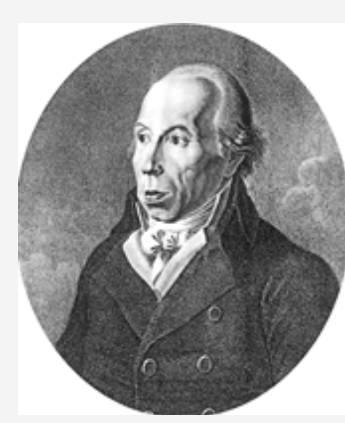

Figure 3: Martin Klaproth (1743-1817)

Klaproth was also convinced that this mineral must have contained a new metal. This discovery coincided with the discovery in 1781 of new planet in the solar system by his compatriot William Herschel and called the planet Uranus [2]. Hence Klaproth named the new metal "uranium" to honor his compatriot. In 1789 he was able to isolate a black heavy solid from the ore which he thought it to be the new metal.

\section{Uranium in the Glass Industry}

In 1851 the Austrian chemist, Adolf Patera (1819-1894) (Figure 4) at the Imperial Geological Institution in Vienna investigated the possibility of the commercial application of Klaproth's discovery. He devised a procedure for preparing "uranium yellow" known at that time as "Uranoxyd-natron". Consequently, a plant was built in 1854 next to the silver smelting operations to process this black uranium mineral for pigment manufacture which was kept a guarded secret and a monopoly of Bohemian glass manufacturers. In 1873, Joachimsthal suffered greatly from a fire and since the silver operation was becoming unprofitable the government of the then Austrian Empire decided to close all the mines.

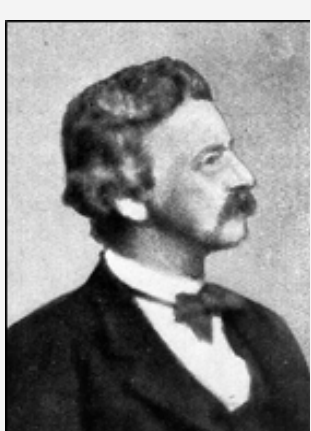

Figure 4: Adolf Patera (1819-1894).

\section{The Discovery of Radioactivity of Uranium}

Joachimsthal was about to become again a ghost town when new discoveries came to its rescue. One year after the discovery of X-rays by Roentgen in 1895, came the discovery of radioactivity by Becquerel (Figure 5) in 1896 when he was trying to find a relation between phosphorescence of uranium salts and the possibility of emission of X-rays. Indeed, he found that uranyl potassium sulfate crystals did fog photographic plates although they were wrapped in black paper. This was followed by the search of Marie and Pierre Curie (Figure 6) for the supposedly new element causing the intense radioactivity of the mineral as compared with pure uranium salts. The Austrian government permitted that $100 \mathrm{~kg}$ of the waste material from the Joachimsthal uranium-based pigment factory to be dispatched to Paris for the Curies. Marie Curie succeeded in the isolation of polonium in 1898 followed by radium in December of the same year. Between 1898 and 1902 the Curies then purchased 11 tonnes of the residue from the Austrian government to process them to produce radium and for further research [3].

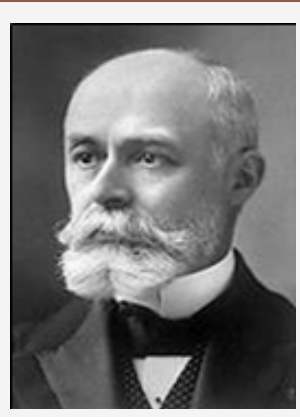

Figure 5: Antoine Henri Becquerel (1852-1908).

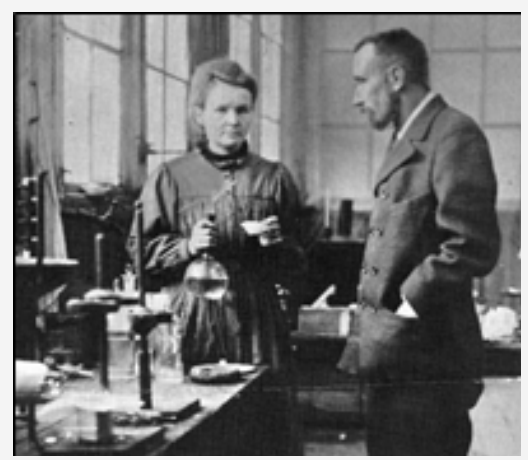

Figure 6: Pierre (1859-1906) and Marie Curie (1867-1934). 
As soon as the Curies announced that radium salts emit light in the dark (Figure 6), two distinguished physicists at McGill University in Montreal, Ernest Rutherford (1871-1937) and Frederick Soddy (1877-1956) immediately took up investigation of this new element. Within few years the area was thoroughly explored and important conclusions regarding the origin of radium and polonium, the radioactive decay process, the structure of the atom, isotopes, etc., were formulated. The discovery in 1903 that radium emitted gamma rays was put into practice for treatment of cancer by the so-called "Curie Therapy", hence the production of radium became in great demand. A small plant was erected east of Paris to treat the Joachimsthal residue shipped from Bohemia, for radium recovery.

When the Curies together with Becquerel were awarded the Nobel prize in 1903, the attention was drawn to Joachimsthal. In the same year, the Austrian Government declared an embargo on the export of ore and residue and asked Carl Auer von Welsbach (1858-1929) (Figure 7) who was specialized in the recovery of rare earths to devise a method for radium recovery. As a result of the embargo, exploration for radium was launched worldwide. Ores were discovered, plants were erected, and small amounts of radium were produced at a very high cost-\$100,000/gram since radium content is only $0.33 \mathrm{mg}$ in one tonne of ore containing $0.1 \%$ uranium [i.e., $1 \mathrm{~kg}$ uranium].

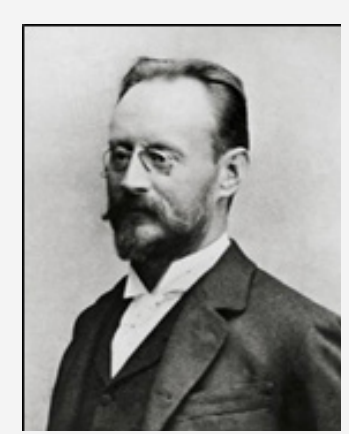

Figure 7:Carl Auer von Welsbach (1858-1929).

\section{The Radium Era}

When late in 1903 the Austrian government declared an embargo on the export of uranium ore and residue from Joachimsthal the stage was set for the exploitation of new sources of radium and for the development of the radium-extraction industry in other countries. In 1905, the Austrian physicist Stefan Meyer (1872-1949) (Figure 8) proved that the Joachimsthal mine waters indicated high content of radium. In 1906, the first radium spa in the world was opened there which attracted many wealthy tourists. A year later, a radium separation unit was installed in the same building that was used for preparing uranium yellow pigment. It became the leading radium producer in the world. In September 1910 the International Radiology Congress was held in Brussels in which leading scientists in the field of radioactivity considered for the first time the question of preparing standard samples for comparison of measurements carried out at different laboratories (Figure 9).

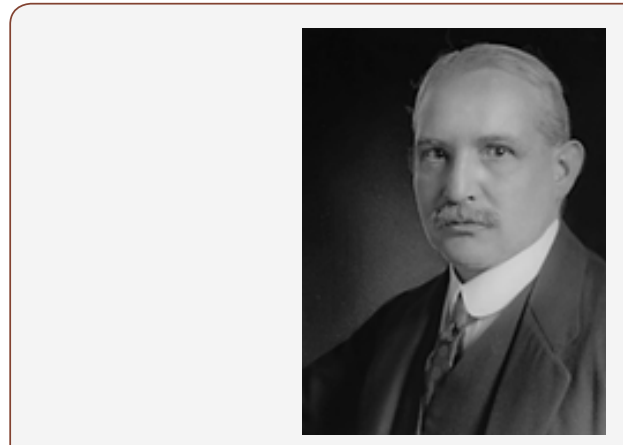

Figure 8: Stefan Meyer (1872-1949).

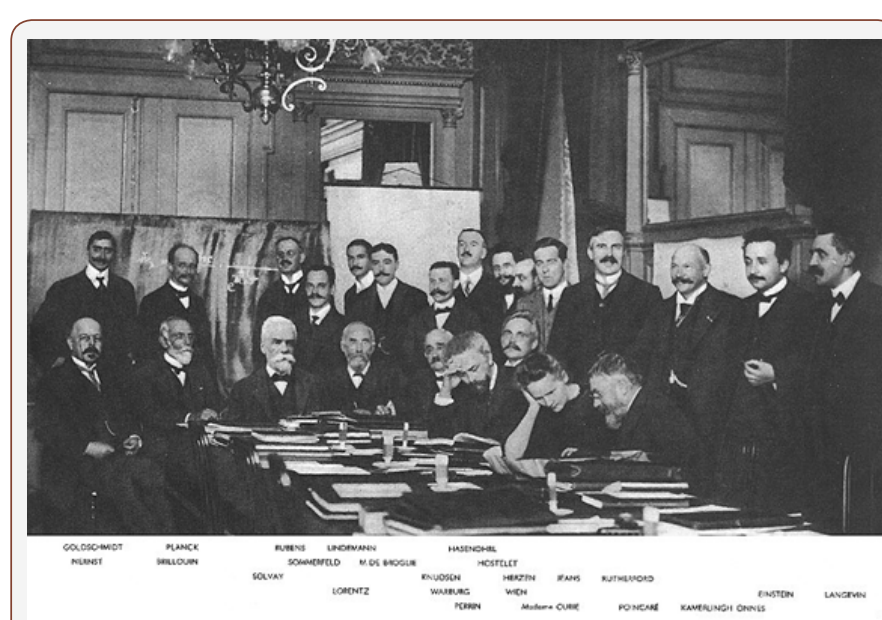

Figure 9: The First Radiology Conference held in Brussels at the request of the Belgian industrialist Ernest Solvay (1838-1922)..

The gradually developing spa business in Joachimsthal resulted in the construction of the luxury Radium Palace Hotel in 1912 which became one of the best spa hotels in Europe and the town became a spa resort of global importance (Figure 10). However, on the outbreak of World War I in 1914, the number greatly declined which reflected badly on the economy. During the war, many hotels were transformed into military hospitals for the wounded soldiers.

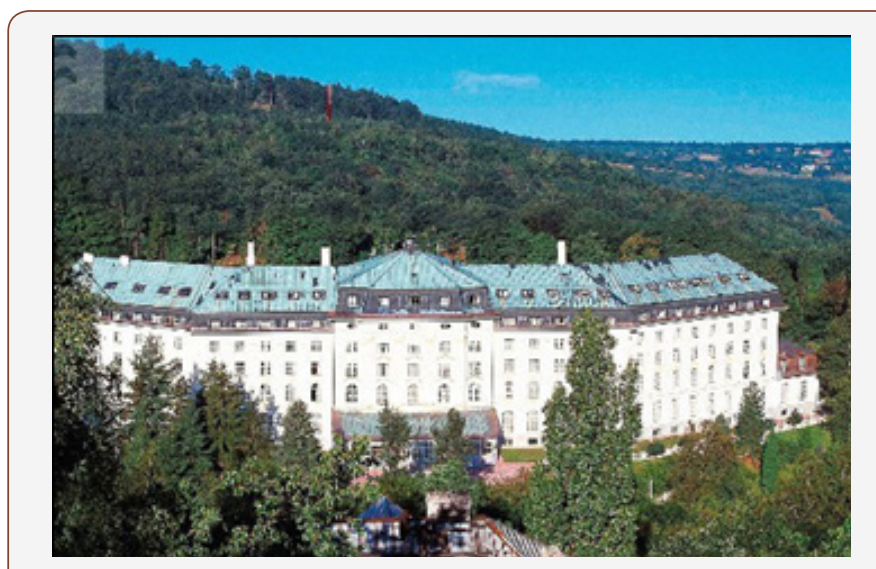

Figure 10: Radium Palace Hotel in Joachimsthal, 1912.

During World War II several hundred grams of radium salts were used in luminescent compounds. They were mixed in small quantities with zinc sulfide, to produce a self-luminous paint for dials of watches, instruments, and for signs. Intensive research all over the world was underway at numerous establishments 
and universities for the recovery of radium and Radium Research Institutes were founded in many countries [4]. Important pitchblende deposits were discovered in what became known as Shinkolobwe in the Haut Katanga district of the Belgian Congo between 1913 and 1915, but wartime pressure of maximum production of copper prevented their exploitation. In 1921 the Union Minière du Haut Katanga began shipping the high-grade ore (averaging about 50\% uranium oxide) to Olen in Belgium for the extraction of radium. As soon as production began in mid-1922 an immediate and final shutdown of almost all radium-extraction operations in USA took place.

The existence of uranium in outcrops along the shores of Great Bear Lake in northwestern Canada had been discovered in 1900 by a pioneering geological survey of the area. In 1931 Edgar A. LaBine (1890-1977) (Figure 11) announced that the extensive of pitchblende deposits containing 30 to $60 \%$ uranium oxide. He developed the deposit under the name of Eldorado Gold Mines. The ore was rich in silver and cobalt. Radium at that time was selling at $\$ 120,000 /$ gram and therefore the discovery was of great significance. A shaft was sunk, and a gravity plant constructed; the site was named appropriately "Port Radium" (Figure 12). Twenty tonnes of this ore were delivered in 1931 to the Bureau of Mines in Ottawa [now CANMET] for the hydrometallurgical treatment. R. J. Traill (Figure 13) was charged with developing a method for the extraction of radium from this ore. In 1933 Labine converted a plant on Port Hope, Ontario and hired Marcel Pochon (1889-1958), a former co-worker of Madame Curie who operated a uranium mine in Cornwall and who came to Canada in 1932.

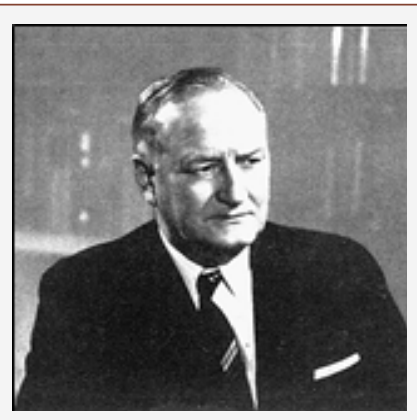

Figure 11: Edgar A LaBine (1890-1977).

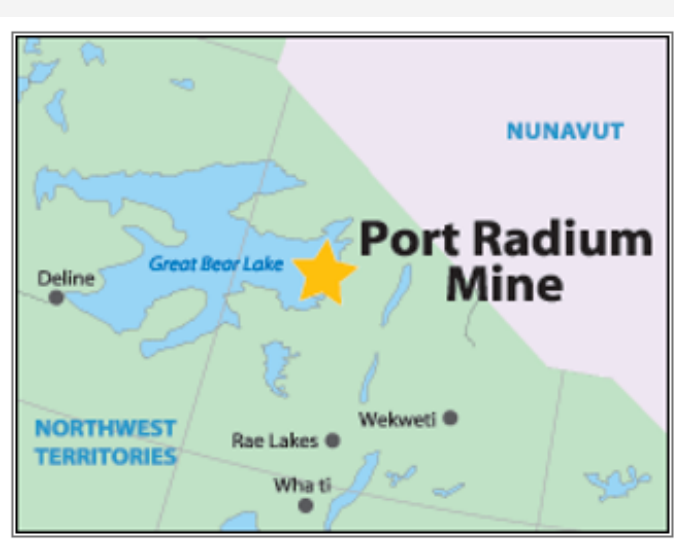

Figure 12: Location of Port Radium in the Canadian North.

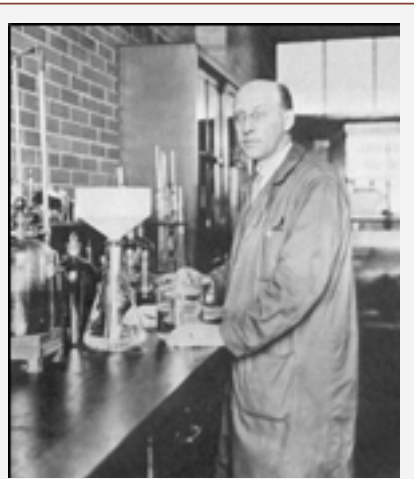

Figure 13: RJ Traill at the Bureau of Mines I Ottawa.

\section{The End of the Radium Industry}

After World War I Joachimsthal became part of Czechoslovakia and was re-named Jáchymov. In 1938, the National Socialists started to propagate the idea of the union of Joachimsthal and the Sudetenland with Germany. This resulted in the invasion of Czechoslovakia by the Nazi troupes. During the German occupation, the Radium Palace Hotel became a branch of the Berlin Hospital, the small hotels transformed into military hospitals, and the mine shafts into prison.

\section{A New Beginning for the Uranium Industry}

During World War II the extraction of uranium became a key part of the industry as nations sought to take military advantage of the newly discovered fission reaction. The physicist Leo Szilard (1898-1964) turned to his professor Albert Einstein (1879-1955) for help to write his letter to President Franklin D. Roosevelt alerting him for the possibility of a uranium bomb (Figure 14). An agreement was immediately drawn and the first difficulty facing the US atomic project was overcome. On September 24, 1942 the order was given to Oak Ridge National Laboratory to construct the first uranium separation plant in the United States [5]. The atomic bomb was tested successfully on July 16, 1945 at Alamogordo testing site in New Mexico. When World War II ended in 1946, the Cold War started.

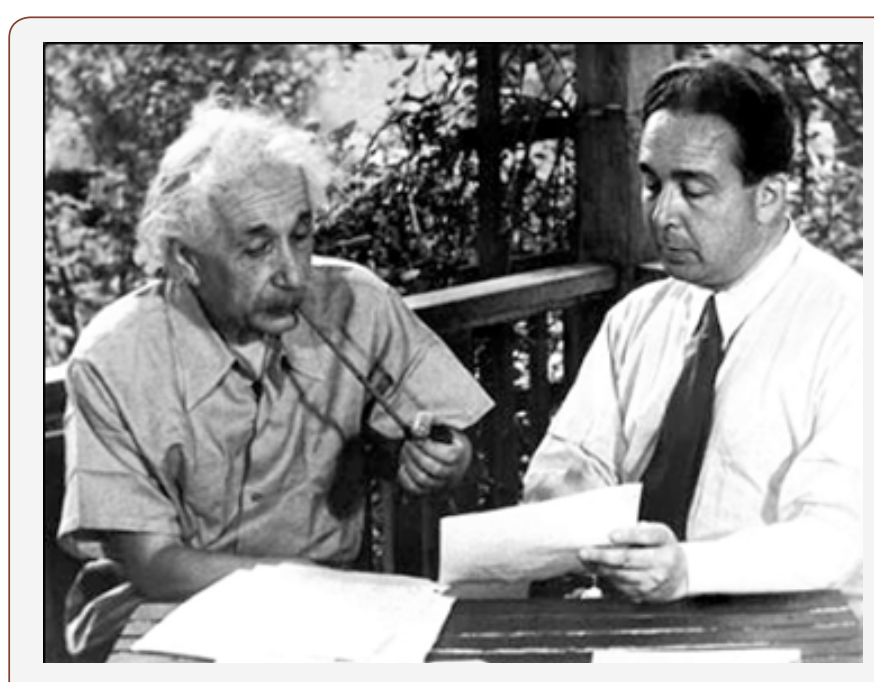

Figure 14: Leo Szilard discussing with his professor Albert Einstein writing a letter to President Franklin D. Roosevelt. 


\section{The Cold War}

A joint German-Soviet company was founded to exploit the uranium deposits that stretched from Dresden in Saxony to Ronneburg in Thuringia in the former German Democratic Republic (Figure 15). So as not to arouse any suspicion, the company was named Wismut, i.e., bismuth, after another metal. The Soviets needed large quantities of uranium to build enough nuclear weapons to keep up in the arms race. A giant industry rose up, shrouded in secrecy. It is estimated that 220,000 tonnes of uranium were shipped to Russia from this region in form of uranium oxide. At one time, 130,000 miners were employed in five mines and two processing plants. The company was a state within a state with its own police force, its own hospitals, stores, sports facilities, car license plates, and residential areas. The former East German state security apparatus, Stasi, had a special spy force there.

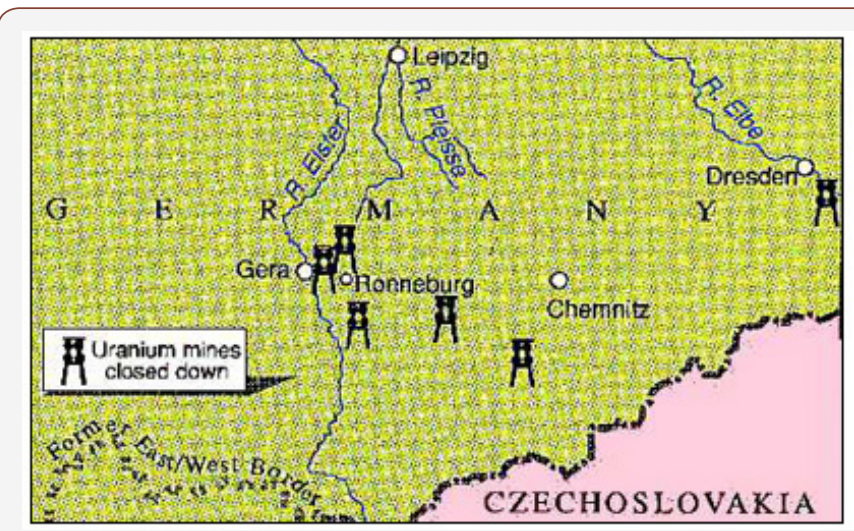

Figure 15: Uranium deposits in the former German Democratic Republic. The Erzgebirge forms the natural border between Germany and Czechoslovakia.

After the fall of the Berlin Wall in 1989, Wismut fell apart. The Soviet Union withdrew, and work came to a halt. Between 1946 and 1990 a total of 7163 uranium miners who had been employed with Wismut died from lung cancer. For 5237 of these, the occupational exposure was recognized as the cause of the disease. At present, still approximately 200 lung cancers of former Wismut miners per year are recognized as occupationally caused [6].

Today the company employees have one task: to remedy the environmental damage that it inflicted in the region for 45 years. Wismut became an environmental rehabilitation company. Its job was to remove over 174 million tonnes of radioactive waste, dry out the mud lakes and re-cultivate the ground of a surface area of about 650 hectars. The costs are enormous; in one year the German federal government has channeled 750 million marks into the region to rehabilitate the area and return the villages to their original state.

\section{Depleted Uranium}

After World War II radionuclides such as cobalt 60 and cesium 137 became available for radiation therapy sources. To-day radium is classified as a waste and methods are devoted to fix it in a form suitable for long-term burial. Naturally occurring uranium contains only $0.7 \%$ of the isotope uranium 235 . Weapon-grade uranium is
$+90 \%$ U235. The leftover from the extraction process is known as "depleted uranium". As of 1998, the United States arsenal has 57,800 steel cylinders of depleted uranium in form of UF6 (Figure 16). Since depleted uranium is heavier than lead it is being fabricated into ammunition to replace lead. It was found to be more effective but has environmental problem. On impact, uranium oxide aerosol is formed due to the resulting high temperature and disperses in the environment. The problem is not radiological but due to the chemical toxicity of uranium. This weapon was used in the 1990s Gulf War and Kosovo conflicts [7].

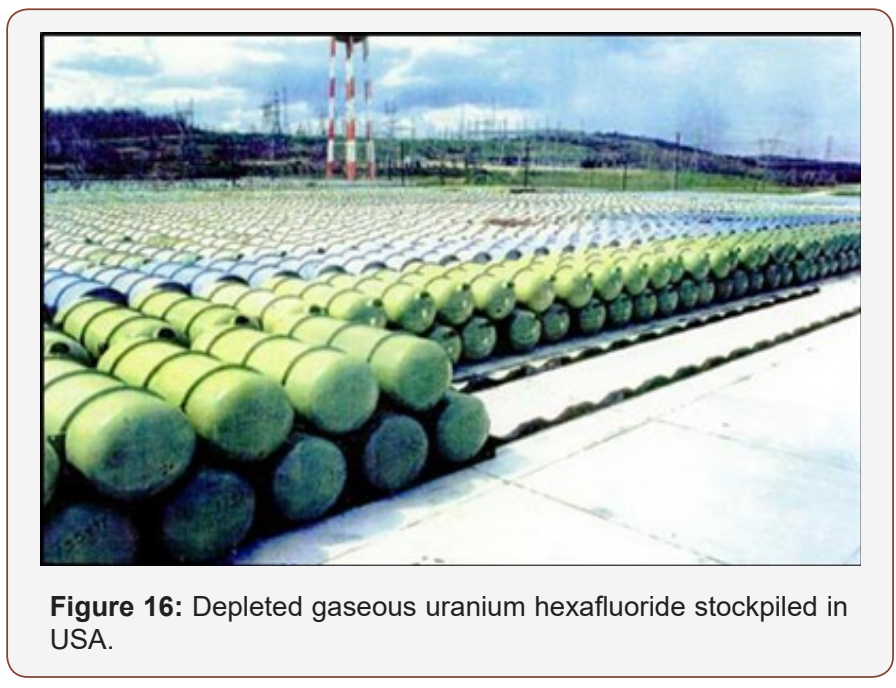

\section{Conclusion}

The history of uranium went through many phases and was closely related to the German mining town Joachimsthal which is now the Czech town Jachymov in Bohemia. When the silver mines were nearly exhausted and Joachimsthal was about to become a ghost town, uranium was discovered there in 1781 and a pigment industry started for coloring glass. This, however, came to an end when the silver mines were exhausted and were closed at the end of the nineteenth century. The discovery of the phenomenon of radioactivity of uranium in 1896 followed by the discovery of radium in uranium ores two years later, created two new industries:

1. The spa industry which was centralized in Bohemia when the radiation from radium became known as a means for cancer treatment.

2. The radium production industry which was centralized in Belgium when rich uranium ores were discovered in the Belgian Congo, and in Canada when rich ores were also discovered in the northern territories.

During World War II, as a result of the discovery of uranium fission, there was a great demand for the metal for military purpose. Hence, the uranium industry rose again. After the War, the demand for uranium continued to increase for the peaceful uses of nuclear energy and the construction of nuclear reactors [8]. This however, resulted in the shutdown of the radium industry as a result of the availability of cobalt 60 from nuclear reactors.

When the uranium industry started after World War II, the ore grade was in general 0.2-0.3\% U308. In the early 1980 's the discovery 
of an ore with $2.5 \%$ U308 at Key Lake in Canada was considered a breakthrough in ore grades. In the 1990's, however, deposits were discovered with 15\% U308 in Canada which rendered Canada the largest uranium producer [9]. But the problems associated with the disposal of enriched uranium and plutonium from nuclear arsenal and stockpile are now a major concern not only to nuclear engineers but also to the uranium industry in general.

\section{References}

1. Bertel R (1999) Gulf War Veterans and Depleted Uranium.

2. Curie E (1938) Madame Curie, Garden City, Doubleday, New York.

3. Diehl P (2011) Uranium Mining in Eastern Germany: The WISMUT Legacy.
4. HA Doerner (1945) Metallurgy of Radium and Uranium. DM Liddell (Edt.), In: Handbook of Nonferrous Metallurgy. Recovery of the Metals, McGraw Hill, New York, USA, pp: 637-655.

5. Habashi F (2002) From Alchemy to Atomic Bombs. Metallurgie Extractive Quebec.

6. Kirchheimer F (1963) Das Uran und seine Geschichte. Stuttgart E Schweizerbart'sche Verlag Buch handlung.

7. Landa ER (1982) The First Nuclear Industry. Scientific American 247(5): 180-193.

8. LeBourdais DM (1959) Canada and the Atomic Revolution. McClelland \& Stewart, Toronto, pp: 1-199.

9. Ozberk E, Oliver AJ (2000) Uranium 2000: proceedings of the International Symposium on the Process Metallurgy of Uranium, September 9-15, 2000, Saskatoon, Saskatchewan, Canadian Institute of Mining, Metallurgy, and Petroleum, Canada. 